\title{
Parasitic isopods on some marine fishes caught from the coasts of Sinop in the Black Sea, Turkey
}

\section{Karadeniz'in Sinop kıyılarından yakalanan bazı deniz balıklarında parazitik isopodlar}

\author{
Sevilay Okkay ${ }^{\text {* }}$ • Ahmet Özer² \\ ${ }^{1}$ Kocaeli University, Faculty of Agriculture, 41285 Kocaeli, Turkey \\ 2 Sinop University, Faculty of Fisheries and Aquatic Sciences, 57000 Sinop, Turkey \\ https://orcid.org/0000-0003-4440-3525 \\ D https://orcid.org/0000-0002-2890-6766
}

\section{How to cite this paper:}

Okkay, S. \& Özer, A. (2021). Parasitic isopods on some marine fishes caught from the coasts of Sinop in the Black Sea, Turkey. Ege Journal of Fisheries and Aquatic Sciences, 38(2), 219-222. DOI: 10.12714/egejfas.38.2.11

\begin{abstract}
Marine fish species such as grey wrasse Symphodus cinereus, common sole Solea solea, knout goby Mesogobius batrachocephalus and rusty blenny Parablennius sanguinolentus were studied for their parasitic isopods on the Sinop coast of the Black Sea. Two cymothoid species (Nerocila bivittata and Nerocila orbignyi) were identified. Nerocila bivittata was found on the body surface and fins of grey wrasse, common sole, knout goby, and N. orbignyi on the dorsal fin of rusty blenny. The prevalence and mean intensity values of each parasite species on fishes were calculated. Fish species mentioned above were all new hosts for $N$. bivittata and $N$. orbignyi in the Turkish coast of the Black sea.

Keywords: Nerocila, Cymothoidae, Black Sea, Isopoda, parasitism

Öz: Karadeniz'in Sinop kıyılarında yaşayan Çırçır balığı Symphodus cinereus, Dil balığı Solea solea, Kaya balığı Mesogobius batrachocephalus and Horozbina balığı Parablennius sanguinolentus deniz balıkları izopod parazitlerinin varlığı yönünden incelendi. Incelenen balıklarda iki cymothoid tür tanımlandı. Nerocila bivittata paraziti çırçır balığı, dil balığı ve kaya balığının yüzgeç ve vücut yüzeylerinde, Nerocila orbignyi paraziti ise horozbina balığının sırt yüzgecinde tespit edildi. Enfeste balık başına ortalama parazit sayısı ve enfestasyon oranı her bir parazit türü için hesaplandı. Karadeniz'in Türkiye kıyılarında gerçekleştirilen bu çalışmada incelenen tüm balık türleri $N$. bivittata ve $N$. orbignyi türü parazitler için yeni konaklardır.

Anahtar kelimeler: Nerocila, Cymothoidae, Karadeniz, Isopoda, parazitizm
\end{abstract}

\section{INTRODUCTION}

Cymothoidae, a family of Isopoda, commonly infect marine, freshwater or brackish-water teleost fishes (Lester, 2005). The genus Nerocila Leach, 1818 is one of the largest of this family with at least 65 species reported from the skin, fin and mouth of their host fishes (Kayış and Er, 2016; Nagler et al., 2016). Members of this genus has been mostly reported from fishes belonging to Labridae and to a lesser extent from other families such as Scorpaenidae, Cottidae, Sparidae, Mugilidae, Centracanthidae, Merluccidae, Monacanthidae, Sciaenidae, Mullidae, Gobiidae, Serranidae, Triglidae, and Platycephalidae (Alas et al., 2008; Nagler and Haug, 2016). Until today, three species namely Nerocila bivittata, $N$. orbignyi and $N$. acuminata have been reported on marine fishes in Turkey (Horton and Okamura, 2001; Öktener and Trilles, 2004; Oğuz and Öktener, 2007; Kırkım et al., 2008; Öktener et al., 2009; Kayış and Ceylan, 2011; Kayış and Er, 2012; 2016; Akmirza, 2014; Er and Kayış, 2015; Özcan et al, 2015) (Table 1).

Studies of cymothoid parasites in wild fish provide an opportunity to obtain significant information on the effects of these parasites on their hosts (Horton and Okamura, 2001). Fish culture expanding significantly in the recent decades are under threat of some pathogenic isopod parasites which have a decreasing impact on its economic value (Horton and Okamura, 2001; Rameshkumar and Ravichandran, 2012; Nagler and Haug 2016). So, such studies will also make further contribution to our current knowledge as well as their interactions with culture fish populations. The Black Sea has an increasing interest for fish culture in the recent years and wild fish surrounding culture cages may have a potential to spread isopod parasites by parasite spillover process (Horton and Okamura, 2001; Balta et al., 2008; Kayış et al., 2009).

In the present study, we aimed to determine isopod parasites present on some marine fishes located in the Sinop coasts of the Black Sea and their prevalence and intensity values of infection. Moreover, this study also aimed to identify parasitic isopods in wild fish that pose a high risk for aquaculture as was previously reported from other culture facilities in Turkey.

\section{MATERIAL AND METHODS}

The grey wrasse Symphodus cinereus (Bonnaterre, 1788) $(n=6)$, common sole Solea solea L., 1758 ( $n=55)$, knout goby Mesogobius batrachocephalus (Pallas, 1814) $(n=35)$ and 
rusty blenny Parablennius sanguinolentus (Pallas, 1814) $(n=48)$ were collected by angling and trammel nets on the

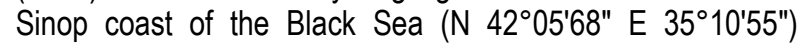
during the period from September 2015 to August 2016. The body surface, fins, mouth and the gill arches of all fish individuals were investigated for isopod parasites at the Faculty of Fisheries and Aquatic Sciences in Sinop, Turkey. Parasite species were identified using an Olympus light microscope (BX53) equipped with a digital camera (DP50) according to the definitions of Bruce (1987), Trilles et al. (1989). Calculation of infestation prevalence (\%) and mean intensity follow the definition indicated by Bush et al. (1997).

\section{RESULTS AND DISCUSSION}

Two cymothoid isopod species were identified; Nerocila bivittata (Risso, 1816) (Figure 1a, b) from grey wrasse
(Symphodus cinereus), common sole (Solea solea) and knout goby (Mesogobius batrachocephalus), and Nerocila orbignyi (Gluerin-Meneville, 1832) (Figure 1c, d) from rusty blenny (Parablennius sanguinolentus). Their infestation sites, prevalence (\%) and mean intensity values are provided in Table 1. Briefly, N. bivittata was found to be attached on the ventral body surfaces, near by the pectoral fin, dorsal fin and caudal fins of its host fishes with the prevalence $16.6 \%$ in grey wrasse, $9.1 \%$ in common sole and $8.6 \%$ knout goby. Loss of scales, extensive skin erosions and haemorrhages were observed in the infested host fishes (Figure 1e, f). On the other hand, $N$. orbignyi was determined on the dorsal fins of its host fish individuals with the prevalence of $2.1 \%$ on the rusty blenny. Hemorrhage or loss of scales was observed on infested host fishes.
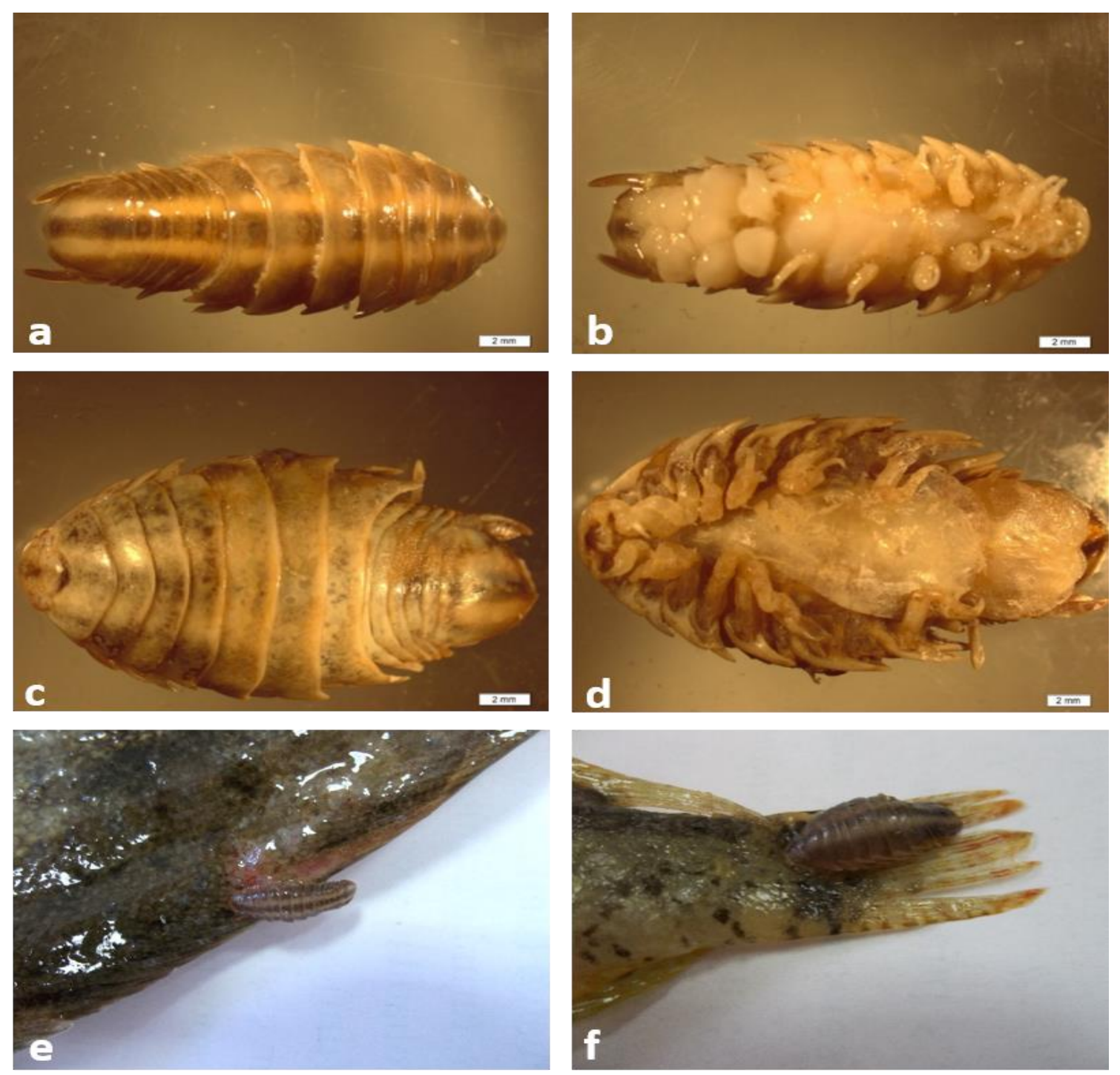

Figure 1. Dorsal and ventral views of $N$. bivittata $(a, b)$ and $N$. orbignyi $(c, d)$. The macroscopic appearances were observed in infected fishes: Hemorrhage, loss of scales and extensive skin erosions $(e, f)$ 
The present study provides new information on the host lists of both Nerocila species. Symphodus cinereus, Solea solea and Mesogobius batrachocephalus are new hosts for
Nerocila bivittata and Parablennius sanguinolentus for $N$. orbignyi. Table 1 summarises current host-parasite list for both isopod species in Turkey.

Table 1. List of host fishes for Nerocila bivittata and N. orbignyi on the coasts of Turkey, and their infestation prevalence (\%) and mean intensity values

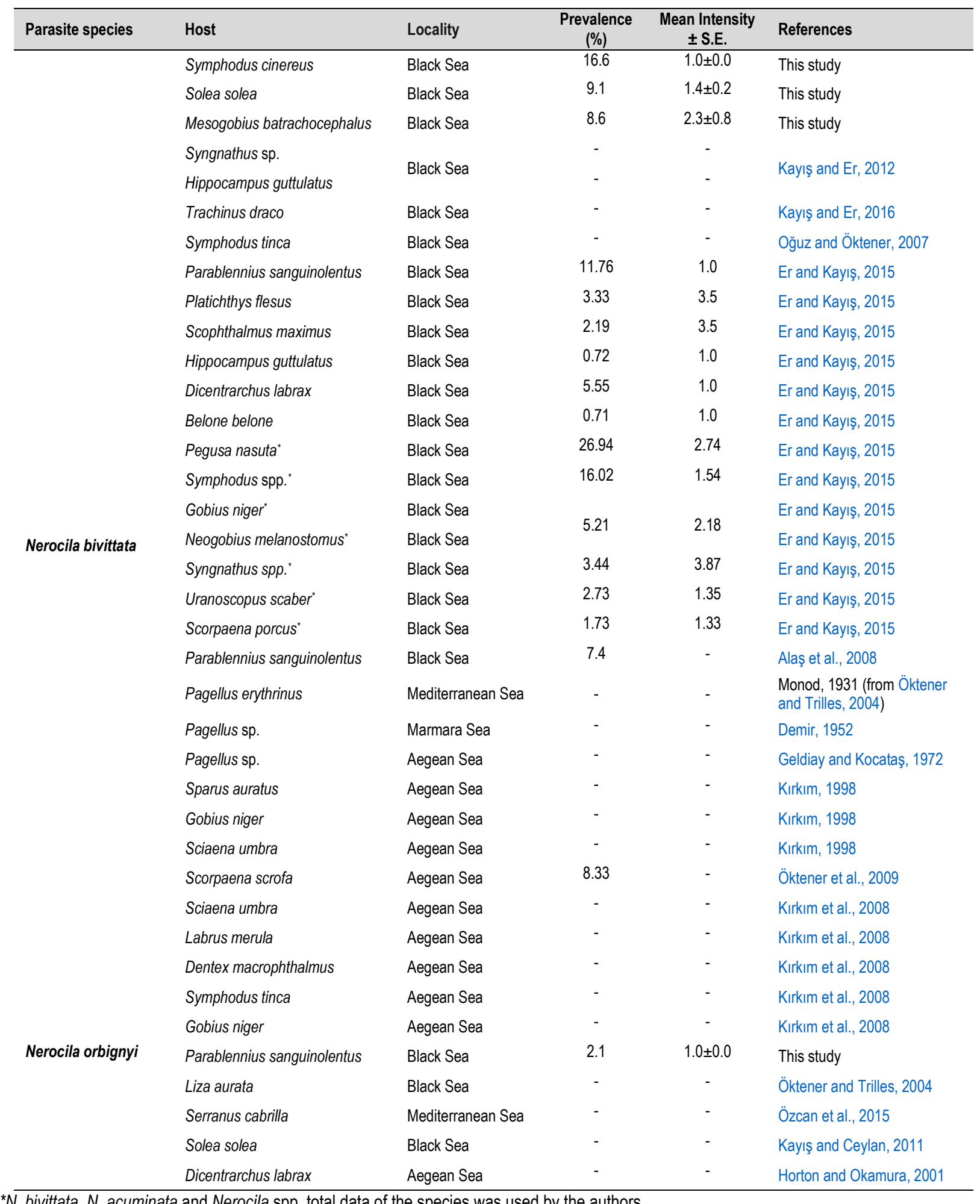


When comparing the prevalence (\%) and mean intensity of infestations for both parasite species with previous reports in Turkey, the infestation prevalence (\%) values found for $N$. bivittata in the present study are higher than those reported by Er and Kayış (2015) and Alaş et al. (2008) (Table 1). This difference may be due to the differences in the number of fishes examined. On the other hand, previous reports for $N$. orbignyi in Turkish marine fishes did not provide any infestation data to make any comparison. It is clear from current data provided in Table 1 that $N$. bivittata infests more fish species than $N$. orbignyi in Turkish coastal areas.

\section{REFERENCES}

Alas, A., Öktener, A., Iscimen, A. \& Trilles, J.P. (2008). New host record, Parablennius sanguinolentus (Teleostei, Perciformes, Blenniidae) for Nerocila bivittata (Crustacea, Isopoda, Cymothoidae). Parasitology Research, 102, 645-646. DOI: 10.1007/s00436-007-0805-3

Akmirza, A. (2014). Metazoan parasites of brown meagre (Sciaena umbra L. 1758) caught near Gökçeada, Turkey. Turkish Journal of Veterinary and Animal Sciences, 38, 299-303. DOI: 10.3906/vet-1209-35

Balta, F., Kayis, S. \& Altinok, I. (2008). External protozoan parasites in three trout species in the Eastern Black Sea region of the Turkey: intensity, seasonality, and their treatments. Bulletin of the European Association of Fish Pathologists, 28 (4), 157-162.

Bruce, N.L. (1987). Australian species of Nerocila Leach, 1818 and Creniola n.gen. (Isopoda: Cymothoidae), crustacean parasites of marine fishes. Records of the Australian Museum, 39, 355-412. DOI: $10.3853 / j .0067-1975.39 .1987 .174$

Bush, A.O., Lafferty, K.D., Lotz, J.M. \& Shostak, A.W. (1997). Parasitology meets ecology on its own terms: Margolis et al. Revisited. Journal of Parasitology, 84, 575 - 583. DOI: 10.2307/3284227

Demir, M. (1952). The bentic Invertebrates of the Bosphorus and Islands Coasts. IU Science Faculty Hydrobiology 3(A), 362-363.

Er, A. \& Kayış, S. (2015). Intensity and prevalence of some crustacean fish parasites in Turkey and their molecular identification. Turkish Journal of Zoology, 39, 1142-1150. DOI: 10.3906/zoo-1409-35

Geldiay, R. \& Kocataş, A. (1972). Isopods Collected in Izmır Bay, Aegean Sea. Crustaceana, 3, 19-30.

Horton, T. \& Okamura, B. (2001). Cymothoid isopod parasites in aquaculture: a review and case study of a Turkish sea bass (Dicentrarchus labrax) and sea bream (Sparus auratus) farm. Diseases of Aquatic Organisms, 46, 181-188. DOl: 10.3354/dao046181

Kayış, S., Ozcelep, T., Capkın, E. \& Altınok, I. (2009). Protozoan and Metazoan Parasites of Cultured Fish in Turkey and their Applied Treatments. The Israeli Journal of Aquaculture - Bamidgeh, 61(2), 93102.

Kayış, Ş. \& Ceylan Y. (2011). First report of Nerocila orbigyni (Crustacea, Isopoda, Cymothoidae) on Solea solea (Teleostei, Soleidae) from Turkish Sea. Turkish Journal of Fisheries and Aquatic Sciences, 11, 167-169. DOI: 10.4194/trjfas.2011.0123

Kayış, Ş. \& Er, A. (2012). Nerocila bivittata (Cymothidae, Isopoda) infestation on syngnathid fishes in the Eastern Black Sea. Bulletin of the European Association of Fish Pathologists, 32(4), 135-139.
In conclusion, the present data provided new host records for $N$. bivittata and $N$. orbignyi as well as their infestation indices in fishes collected from of the Black Sea coast of Turkey. We believe that these parasites might cause some potential negative impacts on cultured fish species due to their dispersal around culture cages.

\section{ACKNOWLEDGEMENTS}

This study was partially delivered in the Iseep-2017 VIII. International Symposium on Ecology and Environmental Problems, 4-7 October 2017, Çanakkale, Turkey as a poster presentation.

Kayış, Ş. \& Er, A. (2016). First record of Nerocila bivittata (Cymothidae, Isopoda) on Greater Weever (Trachinus draco) in the Worldwide. Yunus Research Bulletin 4, 335-339. DOI: 10.17693/yunusae.v16i26717.281033

Kırkım, F. (1998). Investigations on the Systematics and Ecology of the Aegean Sea Isopoda Fauna. PhD Thesis, Ege University, 238 pp. (in Turkish).

Kırkım, F., Kocataş, A., Katağan, T. \& Sezgin, M. (2008). A report on parasitic isopods (Crustacea) from marine fishes and decapods collected from the Aegean Sea (Turkey). Türkiye Parazitoloji Dergisi, 32, 382-385.

Lester, R.J.G. (2005). Isopoda (isopods), p. 138-144. In C. Rohde [Ed.], Marine Parasitology. CBI Publishing.

Nagler, C. \& Haug T.J. (2016). Functional morphology of parasitic isopods: understanding morphological adaptations of attachment and feeding structures in Nerocila as a pre-requisite for reconstructing the evolution of Cymothoidae. Peer Journal, e2188. DOI: 10.7717/peerj.2188

Nagler, C., Haug, C., Resch, U., Kriwet, J. \& Haug, J.T. (2016). 150 million years old isopods on fishes: a possible case of palaeo-parasitism. Bulletin of Geosciences, 91(1), 1-12. DOI: 10.3140/bull.geosci.1586

Rameshkumar, G. \& Ravichandran, S. (2012). Problems caused by isopod parasites in commercial fishes. Journal of Parasite Disease, 38(1), 138141. DOI: $10.1007 / \mathrm{s} 12639-012-0210-4$

Oğuz, M.C. \& Öktener, A. (2007). Four parasitic crustacean species from marine fishes of Turkey. Türkiye Parazitoloji Dergisi, 31(1), 79-83.

Öktener, A. \& Trilles, J.P. (2004). Report on Cymothoids (Crustacea, Isopoda) collected from marine fishes in Turkey. Acta Adriatica, 45, 145154.

Öktener, A., Trilles, J.P., Alaş, A. \& Solak, K. (2009). Cymothoid (Crustacea, Isopoda) records on marine fishes (Teleostei and Chondrichthyes) from Turkey. Bulletin of the European Association of Fish Pathologists, 29(2), 51-57.

Özcan, T., Kırkım, F. \& Sakallı, U. (2015). Serranus cabrilla (Linnaeus, 1758) (Perciformes, Serranidae) a new host record for Nerocila orbignyi (Guérin-Méneville, 1832) (Isopoda, Cymothoidae). Iranian Journal of Fisheries Sciences, 14(4), 1083-1088.

Trilles, J.P., Radujković B.M. \& Romestand B. (1989). Parasites des poissons marins du Monténégro: Isopodes. Acta Adriatica, 30(1/2), 279-306. DOI: 10.13140/RG.2.1.3662.5366 